NBER WORKING PAPER SERIES

\title{
SOME REFLECTIONS ON THE RECENT FINANCIAL CRISIS
}

\author{
Gary B. Gorton \\ Working Paper 18397 \\ http://www.nber.org/papers/w18397 \\ NATIONAL BUREAU OF ECONOMIC RESEARCH \\ 1050 Massachusetts Avenue \\ Cambridge, MA 02138 \\ September 2012
}

The views expressed herein are those of the author and do not necessarily reflect the views of the National Bureau of Economic Research.

NBER working papers are circulated for discussion and comment purposes. They have not been peerreviewed or been subject to the review by the NBER Board of Directors that accompanies official NBER publications.

(C) 2012 by Gary B. Gorton. All rights reserved. Short sections of text, not to exceed two paragraphs, may be quoted without explicit permission provided that full credit, including (C) notice, is given to the source. 
Some Reflections on the Recent Financial Crisis

Gary B. Gorton

NBER Working Paper No. 18397

September 2012

JEL No. E02,E3,E30,E32,E44,G01,G1,G2,G21

\begin{abstract}
$\underline{\text { ABSTRACT }}$
Economic growth involves metamorphosis of the financial system. Forms of banks and bank money change. These changes, if not addressed, leave the banking system vulnerable to crisis. There is no greater challenge in economics than to understand and prevent financial crises. The financial crisis of 2007-2008 provides the opportunity to reassess our understanding of crises. All financial crises are at root bank runs, because bank debt — of all forms - is vulnerable to sudden exit by bank debt holders. The current crisis raises issues for crisis theory. And, empirically, studying crises is challenging because of small samples and incomplete data.
\end{abstract}

Gary B. Gorton

Yale School of Management

135 Prospect Street

P.O. Box 208200

New Haven, CT 06520-8200

and NBER

Gary.Gorton@yale.edu 


\section{Introduction}

Economic development does not result in the elimination of financial crises. The recent financial crisis of 2007-2009 in the United States and Europe shows that market economies, however much they grow and change, are still susceptible to collapse or near-collapse from financial crisis. This is a staggering thought. And it came as a surprise, as financial crises were thought to be things of the past for developed economies, now only occurring in emerging markets. The fact of the crisis occurrence should give pause to economists. While it may take many years to fully understand the recent crisis, in this essay I offer some preliminary thoughts on crises. I do not review the academic literature, but rather selectively raise some issues and in passing mention some research.

The recent crisis emphasizes that a "crisis" is a distinct, singular, event. It also raises questions about what constitutes bank money, and what is a "bank," and what is the "banking system"? Understanding the crisis has run into problems from a lack of data, leaving researchers in the dark on many important questions. Of course, knowing what data to collect requires an understanding of the crisis. Ironically, if governments and economists knew what data to collect prior to a crisis, they would then likely understand the fragility of the system and could possibly avoid a crisis. It seems that a lack of data and the occurrence of a crisis go hand-in-hand. A crisis is a surprise, coming from an unexpected source. As a result, there is little data. There are other inherent difficulties in studying crises. Although crises are perhaps more common than many supposed before the current crisis, still the usable sample size of events is small.

Central to understanding a crisis must be a concept of a crisis. A crisis is a systemic event involving an exit from bank debt. It is sudden and unexpected. In the crisis, the banking system is insolvent if not for suspension of convertibility or government and central bank actions. While this is clear, as an empirical matter, it has been both easy and hard to define a "crisis." Events are observable, but the whole story is often not observable. Historically, in the face of bank runs, banks suspended convertibility so this could be taken as indicating the outbreak of a crisis, although even this has a number of difficulties. In the modern era, it is much harder to define an event as a crisis and to date the start and the end of a crisis. This is usually because of government and central bank involvement or expectations of such involvement. But, governments usually act late and there are not runs on banks in every case. The upshot is that there is no unanimity on which events are crises, and less unanimity with respect to the start and end dates of crises. This is a manifestation of the lack of data. 
What do we know about financial crises? In fact, despite of the above difficulties, we know quite a bit about crises. There are a number of stylized facts about crises that have been identified, some rather recently. The stylized facts can help guide the development of models. It should be the case that models incorporate these facts, some of which have to do with the build-up of fragility prior to the crisis and others with the aftereffects, as well as the crisis itself.

First, we know that financial crises occur in all market economies, though sometimes there are long periods of quiet. Crises occur in developed countries, not just emerging markets. The recent financial crisis shows that the financial system can morph in such a way that a crisis can occur after a fairly long period of quiet. The frequency of financial crises historically and internationally strongly suggests that there is a structural or inherent problem with bank debt.

Secondly, we know that crises are exits from bank debt. But, the recent crisis centered on forms of bank debt that are quite different from most (but not all!) previous crises. Can our theories accommodate these other forms of debt? Generating such an event in a model seems harder when the money involved is, for example, sale and repurchase agreements (repo). In this form of money, each "depositor" receives a bond as collateral. There is no common pool of assets on which bank debt holders have a claim. So, strategic considerations about coordinating with other agents do not arise. This is a challenge for theory and raises issues concerning notions of liquidity and collateral, and generally of the design of trading securities-private money.

There are other facts we know about crises. A crisis is a sudden event, a structural break or a regime switch. A crisis is not just a bad outcome in a setting where there is a range of bad outcomes. A crisis is a uniquely bad outcome. Crises are preceded typically by credit booms. They tend to occur at business cycle peaks. They are very costly.

But, there are many things we do not know about crises. We do not know about the dynamics of crises, why agents form suspicions about the value of the assets or collateral backing bank debt. We do not know how agents' expectations of government actions affect the dynamics of crises. We do not know if the preceding credit booms finance productive activity. We do not know what policies can prevent crises, without repressing the banking system. We do not know much about which regulatory systems have been successful at mitigating the occurrence of crises (except by casual observation). We do not know much about how to update measurement systems to detect the buildup of systemic risk. 
Overall, the scales tip towards the "do not know" side. In this essay I explore these issues, many of which are areas of ongoing research. The essay proceeds as follows. In Section 2 I examine definitions of crisis and outline the difficulties in empirically defining crises. In Section 3 I summarize the stylized facts about crises. Section 4 is devoted to crisis theory, in particular, the model of Diamond and Dybvig (1983). In Section 5 I inquire more generally about the private production of debt securities for transactions and the relation to crises and macroeconomics. Final thoughts are collected in Section 6.

\section{What is a Financial Crisis?}

Answering this question is not straightforward either as an empirical matter or as a theoretical matter. In this section I look at practical definitions used for empirical work and in a later section I look at theoretical concepts. One must be informed by the other. We start with a practical definition, which can be used for empirical work.

A "financial crisis" occurs when bank debt holders run on all or many banks demanding that banks convert their (short-term) debt claims into cash to such an extent that this demand for cash cannot be met. The banking system must then be saved by the central bank or the government. Or, if there is no run on banks-or no observed run-- then a financial crisis is a situation where there is significant impairment to the banking system, resulting in closures, bailouts, nationalization, blanket insurance guarantees, or other government assistance.

This is a practical definition because its main elements can be observed. Either runs are observed or the interventions are observed. Historically, most bank runs could be observed (by those outside the banking system). And if a run cannot be observed (as was the case for most observers in the recent crisis), the effects of the run can be observed - bailouts, closures, etc. The magnitude of the event is eventually apparent, and it is deemed a "crisis."

The first part of the definition states the basic points, which we will return to below. It says that the problem is "systemic," that is the banking system cannot meet the demands of the debt holders. In this sense, the system is insolvent. This was clear in the recent financial crisis, although the banking system was the shadow banking system not the regulated banking sector. Federal Reserve Chairman Ben Bernanke, in his Financial Crisis Inquiry Commission testimony, noted that of the "13 . . most important financial institutions in the United States, 12 were at the risk of failure within a period of a week or two" (Bernanke (2010)). The systemic aspect should be stressed, as this will play an important role in developing a concept of a financial crisis. A "crisis" is not just a bad event. 
The first part of the definition refers to "banks" and "bank money" without stating what these terms mean. Until the recent financial crisis, these terms may have seemed clear. "Banks" are regulated firms that issue demand deposits. But, the financial crisis illustrates that the "banks" and "bank money" have changed over the last thirty years. "Banks" and bank money change their forms through time. Although bank money is typically thought of demand deposits, that was not always the case. Demand deposits developed over time and the extent of their use as money was not understood for many decades (in the $19^{\text {th }}$ century in the U.S.). See Gorton (2012). Bank money takes many other forms, especially historically. Examples of other forms of private money include private bank notes, commercial paper, bankers' acceptances, bills of exchange, and sale and repurchase agreements (repo). Bank debt--private money-is invariably short-term debt issued by certain kinds of firms. The fact that there are other forms of bank money will present some problems for theories, as discussed below.

The second part of the definition relies on observing government actions, taken to address an impending or realized insolvency of the banking system. The government is reacting to a crisis that has already occurred and is causing banks to fail. Often there was a bank run, perhaps a piecemeal run in which the bank debt is attacked over time, an incipient run. Behind this part of the definition a counterfactual is posed. The point is that there would have been a run had it not been for expectations of the government actions. When there is an expectation that the government or central bank will intervene there may be no run on the banks (although in most cases there are runs anyway, though they may come late in the crisis). Events are driven by expectations that the government or central bank will act, but then it may not act in the end, or it acts late. Events then appear chaotic. One need only look at Indonesia during the Asian Crisis to see an example of this. ${ }^{1}$ The financial crisis may also involve a currency crisis as well. The result is that each crisis seems different, special, although at root it is always about bank runs.

Because expectations are unobservable, a practical definition of a crisis-necessary for empirical work-turns on observed bank bailouts or failures. As the recent crisis dramatically illustrated, these eventsbailouts and failures-are the result of the crisis, but the crisis-the run-- was not observed by those outside the banking system (academics, regulators, the media, the public). Those outside did not observe the run, but only saw the resulting bailouts and failures. These events then are deemed to be

\footnotetext{
${ }^{1}$ See, e.g., Djiwandono (2000) for an eyewitness view of the events in Indonesia. Also, see, for example, Enoch, Baldwin, Frécaut and Kovanen (2001).
} 
the "crisis." This is a mistake. Bailouts and failures are the effects not the causes. Something caused the failures, and this causal factor occurs rather suddenly.

For modern crises, the practical problem is that understanding crises by outsiders relies on observed events such as firm failures or government actions, and government statistics. This problem is manifest in defining and dating crises. In the modern era the determination of whether an event is a crisis, and when it starts and ends, is based on governments' actions because these are readily observable. Boyd, De Nicolò and Loukoianova (2011) study the four leading classifications and dating of modern crisis events. ${ }^{2}$ They show that for many crises the dating of the start and end dates differ quite significantly. There is also some disagreement on which events are crises. Further, they show that the start dates are late. ${ }^{3}$ This is because the government actions follow the crisis which has already begun, often in the form of a quiet run (see Gorton (2012)). The dating of the start and the end of a crisis is largely based on contemporary accounts of the crisis, and there is ambiguity.

The economic data available to study crises are usually scanty. Without much data it is hard to do research. Why is collecting data so hard? First, there is the issue of what data to collect, so there must be some prior detailed knowledge of the world in order to know what should be collected. But, outsiders do not know what to collect. They lack the institutional knowledge to know what to collect. So, academics typically focus on the data that are available. Second, even knowing what to collect, there is usually no real way to collect the data. Firms are no help. Similar to the Tennessee Williams play, we must rely on the kindness of (in this case) traders to provide data purely out of a civic duty. This is not a good position for the academe to be in, but there may be no alternative.

The problem of the lack of data cannot be overemphasized. In the recent crisis, many of the most central questions cannot be addressed adequately because of a lack of data. Then the details of the causes of the crisis - the run-and the dynamics of the crisis cannot be formally documented. Instead, research tends to focus on the topics where there are existing data sets, and then the emphasis and attention shifts to those topics. This then distorts our picture of the crisis. Some topics assume enormous importance only because there is data on these topics. Worse still the absence of evidence on other topics is sometimes taken to be evidence of the absence of the importance of these topics, a

\footnotetext{
${ }^{2}$ These are the classifications of Demirgüç-Kunt and Detragiache (2002, 2005), Caprio and Klingebiel (1996, 1999), Reinhart and Rogoff (2008), and Laeven and Valencia (2008). Laeven and Valencia's database is available at http://www.luclaeven.com/Data.htm .

${ }^{3}$ Boyd, De Nicolò and Loukoianova (2011) use empirical measures of adverse shocks to the banking industry to forecast subsequent government responses. The government responds after the shocks.
} 
logical fallacy. As a result, there can be a large gap between anecdotal and eyewitness accounts and what can be more formally documented.

It is easy to see why the empirical study of financial crises is difficult. While crises are frequent in the sense that they occur in all market economies, still the sample size available for econometric study is small and often the relevant data are not available. Historical research can avoid the problem of expectations of government or central bank intervention. I have studied the U.S. National Banking Era, for example, for this reason. But, this presumes that the historical evidence is really about the same type of event as the crises of the modern era. If crises are always about bank runs, then it makes sense to study historical events.

The problem feeds on itself. Without empirical research on crises, theory is unconstrained and will be lacking content. Without theory the notion of a crisis is vague and there is no guide for empirical work. There ends up being no anchor for research. Without addressing these issues, it is hard to make useful policy recommendations. Despite the practical difficulties in empirically identifying crises and their associated timing, we can safely conclude that there are events-"crises" - that are worse economic outcomes than recessions.

\section{What do we know about Financial Crises?}

Not enough is known about financial crisis. But, I would say that we do know the following facts about financial crises.

1. Financial crises occur in all market economies.

2. Economies can experience long crisis-free periods.

3. Financial crises are sudden and always involve private money - - the money markets in the recent crisis.

4. Crises are typically preceded by credit booms.

5. Crises occur at or near business cycle peaks, when the macroeconomy weakens.

6. Recoveries are prolonged following a financial crisis.

7. Financial crises are costly.

The first point is familiar to historians; market economies in different countries have experienced bank runs throughout their histories. But, these experiences vary internationally and over time. One 
important factor in determining the frequency of crises is the industrial organization of the banking system, in particular whether branching is allowed or prohibited, whether the banking system is a few large banks or many small banks. Also affecting the frequency of crises is the presence or absence of private bank clearinghouses or an effective central bank, and the presence or absence of effective deposit insurance, bank examination and regulation. Based on these factors countries are more or less likely to experience crises. See, e.g., Calomiris and Gorton (1991).

The industrial organization of banking determines the size and structure of the interbank market, which seems to be a critical factor in determining the likelihood of a crisis. For example, in the U.S. in the National Banking Era the regulations and the geographical distribution of economic activity led to "reserve pyramiding," where country banks would deposit their reserves (at interest) with reserve city banks (in large cities), and then they in turn would deposit reserves (at interest) in central reserve city banks (in still larger cities). This intermediation chain, and associated "fictitious reserves," as they were called, induced fragility. ${ }^{4}$ This was not the case in England, for example, where the Bank of England's powerful presence was felt. In general, the structure of interbank markets seems very important in affecting the fragility of the system. The structure of the interbank market may also have played a critical role in the recent financial crisis.

But, and this should be stressed, the heterogeneity of countries' crisis experiences should not obscure the central point of the recurring experience of crises. I take this to be one of the main points of Kindleberger (1978, 1993), Reinhart and Rogoff (2009) and Cassis (2011)-crises occur over and over. Laeven and Valencia (2012) count 147 banking crises over the period 1970-2011. And, in particular, developed economies have crises. Reinhart and Rogoff (2008a) note that "for the advanced economies during the full sample, the picture that emerges is one of serial banking crises." Crises in emerging markets have also been frequent, and have some important unique features. ${ }^{5}$ Bordo, Eichengreen, Klingebiel, and Martinez-Peria (2001) look at 120 years, 1880-2000, and argue that the frequency of crises has doubled since 1973. And, Schularick and Taylor (2009, p. 12) note that "the frequency of

\footnotetext{
${ }^{4}$ See, e.g., Mills (1908). The term also refers to the float of checks; see Lockhart (1921a, b), Sprague (1910), and Richardson (2006). There is a theory literature on interbank markets; see, e.g., Rochet and Tirole (1996), Allen and Gale (2000), Freixas, Parigi, and Rochet (2000), and Dasgupta (2004). And, with respect to modern interbank markets, there is also an empirical literature and simulations of interbank exposures; see Upper (2006).

${ }^{5}$ For example, see Diaz-Alejandro (1985), Calvo (1995), Kaminsky and Reinhart (1999), and Dornbusch (2001).
} 
banking crises in the 1945-71 period was virtually zero; but since $1971 \ldots$ crises became much more frequent." We do not know why this is so.

There is much work to be done to understand the cross-section and time series heterogeneity of crisis experiences internationally and historically. In particular, it is important to understand the cases where no crisis has occurred for a significant period of time, suggesting that some regulatory or central bank framework was effective. One outstanding example of this is the period in England following the Overend, Gurney Crisis of 1866 until 2007. The prolonged stability of the Canadian banking system is another example. ${ }^{6}$ And finally, another example is the period in the U.S. from the advent of deposit insurance in 1934 until 2007, a period I have elsewhere called the Quiet Period. Why were there no crises during these periods? This is an important question to answer to be able to design regulations prevent future crises. Studying the absence of crises is as important as studying crises.

That crises always involve runs on private bank debt is clear historically, but perhaps less clear in the modern era. Laeven and Valencia (2008) report that 62 percent of the crises in their modern era sample had bank runs. In discussing the counterfactual, related to the definition I gave above, I said that the other crises would have had bank runs had not expectations and subsequent actions of the government and the central bank not stopped the runs. This point is clearly not obvious. The accounts of each crisis suggest that this is in fact the case. Here is where eyewitness accounts and contemporary narratives of crises are very important. The dynamics of the runs are changed by the existence of a central bank and the government, and in many cases specific policies were adopted that prevented runs, for example, a blanket guarantee on demand deposits. See the discussion in Gorton (2012).

Financial crises are not predictable events although because of credit booms the buildup of fragility is observable. That credit booms often precede financial crises is well-documented, but not well understood. Documentation is provided by Gourinchas, Valdes, and Landerretche (2001), Collyns and Senhadji (2002), Barajas, Dell'Ariccia, and Levchenko (2007), Schularick and Taylor (2009), Reinhart and Rogoff (2009), Borio and Drehmann (2009), Mendoza and Terrones (2008, 2011), Claessens, Kose, and Terrones (2011), and Elekdag and Wu (2011), among others. These studies use different definitions of "credit boom," although the result that crises are best predicted by a "credit boom" seems robust to the definition. Still, this is a bit troubling.

\footnotetext{
${ }^{6}$ See Bordo, Rockoff and Redish (1994) and Ratnovski and Huang (2009) for discussions of Canada.
} 
Two issues are not really understood. First, although there is some evidence that the credit booms are associated with house price increases, it is not clear more generally what all the credit is being used for. What is the borrowed money being spent on? Secondly, it is not clear that these credit booms are necessarily evils to be avoided. Are the booms supporting productive activity? Fragility builds-up perhaps, but it may also be the case that the credit is supporting productive activity, at least at the start of the boom. We don't know. See Rancière, Tornell, and Westermann (2008) and Gorton and Ordoñez (2012). These are questions for future research.

Financial crises do not happen at random times, but occur near the peak of the business cycle after the credit boom. Gorton (1988) studied the U.S. National Banking Era, 1864-1914, a period during which banking panics regularly occurred, and shows that this is the case. In that study I showed that the arrival of news forecasting a recession resulted in a panic when the news variable exceeded a threshold. The news arrived near business cycle peaks. In the modern era, the results that there are links between financial crises and recessions are similar. For example, Demirgüç-Kunt and Detragiache (1998) examine the period 1980-1994 and "find that low GDP growth, excessively high real interest rates, and high inflation significantly increase the likelihood of systemic problems in our sample" (83). Also see, e.g., Kaminsky and Reinhart (1999).

Historically, economic downturns that involve a financial crisis are worse than the usual downturns. Cerra and Saxena (2008) find that downturns associated with a financial crisis result in output losses of about 7.5 percent of GDP over the subsequent ten years. Reinhart and Rogoff (2009a, b) find that peak-to-trough declines following a crisis average about nine percent. Toujas-Bernaté and Joly (2011) look at 154 countries over 1970-2008 and find long-last output losses; output is reduced by ten percent after eight years. Reinhart and Reinhart (2010) find that GDP growth and housing prices are significantly lower and unemployment higher in the decade following a crisis. Caballero, Hoshi and Kashyap (2008) provide empirical evidence on a channel that prolongs crises, in the case of Japan. Also, see Kannan (2010), who looks at industry level data and finds that industries relying more on external finance grow more slowly following the crisis. Related to the aftermath of crises being worse, Jorda, Schularick and Taylor (2011) show that "more credit-intensive booms tend to be followed by deeper recessions and slower recoveries." 
But, overall the interaction between financial crises and the business cycle is not clear. The causality is not clear. ${ }^{7}$

Crises seem very costly, but these costs are hard to measure. In particular, it is hard to isolate costs that are due to the crisis and not due to the recession that might have occurred even had there not been a crisis. Aside from measures of output loss (relative to trend), there are other measures, such as the net amounts used to resolve bank failures and also fiscal costs. But, the amounts used to bailout banking systems are usually transfers from taxpayers. These transfers may be distortionary and hence costly, but these costs are very hard to measure. Researchers often use the size of the transfer as a proxy. Researchers have tried to address these cost measurement issues in different ways. See, as examples, Laeven and Valencia (2010), Dell'Ariccia, Detragiache and Rajan (2008), Boyd, Kwak and Smith (2005), and Hoggarth, Reis, and Saporta (2002). Other costs, such as social, health and psychological costs have not been systematically measured. ${ }^{8}$ See Gorton (2012) for a discussion of the costs literature.

These stylized facts provide some broad guidance for a theory of crises. To be clear, financial crises are bank runs, though the form of the "banks" and the "bank money" changes. Bank debt is vulnerable to runs, and crises are usually an integral part of the business cycle in market economies. The facts are not consistent with crises being caused by distortions from government policies, which may be important but which cannot be the basis for a theory of crises. Government actions to prevent crises or to save the banking system in a crisis may be problematic, but they are responses to possible crises, effects, not causes. The stylized facts require explaining the credit boom prior to the crisis as well as the subsequent prolonged below average recoveries. And, it is important to explain why economies can have long periods of quiet, perhaps due to the success of laws and regulations.

But, as I mentioned in the Introduction, there is much we do not know about crises. We do not know the details of how crises are triggered, or what happens during a crisis to exacerbate or allay agents' fears. We do not really know what policies prevent crises. We do not know much about credit booms, how they get started, why they persist, how they end. We do not know how, or if, credit booms are related to asset price increases. We do not know the links between crises and business cycles.

\footnotetext{
${ }^{7}$ There is some interesting work on crises exacerbating downturns. See, for example, Bordo and Haubrich (2009) and Ziebarth (2011).

${ }^{8}$ Though see Furceri and Zdzienicka (2009) on the effects of crises on human capital.
} 


\section{Crisis Theory}

Theoretically, a financial crisis is defined by two essential points. First, a crisis is a singular event. It is a rending, a sundering, or a rupturing, of the normal state of affairs in money markets. A financial crisis is not the worst outcome on a continuum of bad events. There is no continuum in an important sense. There are booms and recessions, and then here are crises. A crisis is a distinct event. Something happens to make a crisis fundamentally different from the usual economic downturn. Second, while each crisis has important unique features, crises have a common root cause. There is a structural feature of bank debt that makes the debt vulnerable to runs. And the bank debt in question is not just demand deposits. Financial crises are always about bank runs. The bank runs either occur or would have occurred had the government or central bank not intervened or been expected to intervene.

The first point says that a "crisis" is not simply a particularly "bad state" of the world. A crisis is fundamentally different, a different regime. There are normal non-crisis states and there is an extraordinary crisis state. This is why Anna Schwartz (2007) said that "a decline in asset prices of equity stocks, real estate, commodities; depreciation of the exchange value of a national currency; financial distress of a large non-financial firm, a large municipality, a financial industry, or sovereign debtors - are pseudo-financial crises" (p. 245). They may be bad events, wealth may be destroyed or cleanup costs high, but they are not crises. A financial crisis is a systemic event. The entire financial system is engulfed. The failure of a large firm or problems in one sector, e.g., savings and loans or the auto industry, are not crises in this sense.

Financial crises repeatedly occur in market economies. The second point is that there is a reason for this. There is a root cause. Agents in the economy need private money to transact. But, this money is vulnerable to runs. Bank runs are crises. Financial crises are caused by bank runs.

The root of the financial crisis problem was elegantly identified by Diamond and Dybvig (1983). ${ }^{9}$ Diamond and Dybvig studied a setting where banks must use long-term collateral to back demand deposits. Agents need the demand deposits because of potential shorter-term liquidity needs. The investments are "long" in the sense that if they are liquidated early there is a very low return. "Long" also means relative to the required frequency of agents' transactions for consumption or other shortterm needs. The agents need demand deposits to smooth consumption, which is uncertain as some

\footnotetext{
${ }^{9}$ There is a large literature on the Diamond and Dybvig model, many extensions and discussions, but I will, for the most part, not go into this literature.
} 
agents may want to consume early. An essential feature of the model is that the interest rate offered on the demand deposits to achieve this smoothing is such that if all agents want to consume early (by withdrawing from the bank), then the bank cannot satisfy these demands. This is the critical fragility in the economy.

A very important point is that there is no way around this basic horizon problem in any market economy. People eat lunch every day, but it takes a long time to build a factory and produce output. People need to pay for their lunch before the output is realized. This timing is fundamental. Bank debt used for transactions can only be backed by these long investments (which have a low return if liquidated early). The private sector cannot produce riskless assets. These basic facts mean that financial intermediaries will always be involved in "maturity transformation," a term which just restates this fact.

"Maturity transformation" is not a choice. It can't be regulated away. It is inherent in any economy which produces private bank money, that is, any market economy. It is a fundamental fact. Bank money can only be backed by longer-term investments. As we will see later, agents in the economy will strive mightily to design bank debt to overcome this problem. But, without the government, bank debt will always be vulnerable.

Uncertainty about consumption timing is a risk the agents want to shed using bank debt. The problem of long-term collateral backing bank debt is a necessary but not a sufficient condition for crises to occur. To get a crisis-a bank run, Diamond and Dybvig introduce a source of uncertainty that is quite special. It is the uncertainty that each individual bank depositor faces about the actions of other deposit holders. Depositors care about the actions of other depositors if there is a common pool of assets on which they all have pari passu claims-the bank's assets-- but the claims are honored sequentially (so they are not in fact pari passu). Note that the assumption of sequential service means that the payout of the bank to an individual depositor depends on the actions of the other depositors. How much a depositor gets back depends on his place in the line. In this setting, depositors may run if they think other depositors are going to run. Each depositor has an incentive to be first in line to withdraw at the bank if he believes that other depositors are going to line up. Beliefs about other depositors' beliefs must depend on something and in Diamond and Dybvig beliefs are coordinated by an extraneous random signal, a sunspot.

The bank run, due to the beliefs coordination problem, displays the second essential condition of the definition of a crisis, discussed above. A run in the Diamond and Dybvig model is fundamentally 
different from the normal state of affairs. There are no "small" crises in the Diamond and Dybvig model. There are two outcomes: no crisis and crisis. The crisis is a distinct, very different, event. This is consistent with the empirical evidence that there are distinct events that can be called "crises" and which are clearly much worse outcomes than recessions or Anna Schwartz's pseudo-financial crises. The model lays out a convincing setting and shows that the outcome can be very different than the normal state of affairs, a run can occur-a crisis. This was the first model that displayed the two essential points articulated above. In this sense, it provides a coherent picture of a financial crisis.

But, as a theory of crises, the Diamond and Dybvig model is not completely satisfactory. The very phenomenon we want to explain, why there is a loss of confidence, is not explained - it is "sunspots." That is, each agent believes that the other agents will run when they observe "sunspots." While the coordination device is called "sunspots," this is just a name for the multiple equilibria that can occur in the model. There is no explanation for why the economy switches from one equilibrium to another.

The issue of belief coordination is especially troublesome. There is no explanation for why a run would suddenly occur. And so, no empirical predictions or policy implications follow. The empirical evidence shows that financial crises are preceded by credit booms and are related to the business cycle, and that agents are prone to run when public information arrives forecasting a recession. The link between the preceding credit boom and the business cycle provides the structure for belief formation.

Economists have attempted to address the issue of belief formation in the Diamond and Dybvig model (and other similar models). Using the global games approach of Carlsson and van Damme (1993), if some noise and asymmetric information are added to the model the multiplicity can be eliminated or reduced. If each depositor privately observes a signal about the future value of the banks' assets, then the equilibrium can be unique if their private signals about the banks' assets are sufficiently accurate. In this way, the belief coordination problem can be linked to economic fundamentals. There is still a threshold effect, so a crisis is a distinct event. ${ }^{10}$ Coordination games can generate large changes in agents' behavior without large changes in economic fundamentals. Agents change their beliefs about the actions of other agents and this can have a large effect. This is a general statement which applies to many phenomena, as long as they can be modeled as a coordination game, where the payoff to any one agent depends on the actions of other agents.

\footnotetext{
${ }^{10}$ The important papers are Morris and Shin (2001) and Goldstein and Pauzner (2005). The multiplicity of equilibria can be eliminated in other ways; see, e.g., Postlewaite and Vives (1987).
} 
It is important to note that this is a purely formal fix-up to a vexing problem arising in the Diamond and Dybvig model. It can't be tested; no one has every articulated the nature of the private information that bank debtholders might realistically have learned. Kelley and Ó Gráda (2000) and Ó Gráda and White (2003) study the details of who ran on the Emigrant Industrial Savings Bank in 1854 1nd 1857. It is hard to see what the nature or role of the alleged private information.

There are still problems. First, the issue of belief coordination only arises for some forms of bank money. Demand deposits are claims on a common pool of assets - the bank's portfolio of loans, the case where belief coordination arises as a problem. Other forms of bank money can differ from the Diamond and Dybvig model in important ways. There may be a maturity date on the claim, even if it is a short maturity, and there may be no common pool problem. If a "depositor" does not have a claim on a common pool of bank assets, then the actions of other depositors are irrelevant; beliefs about other agents' beliefs then do not matter. Or, if there is no sequential service, no lining up, then claims really are pari passu. But, financial crises are not just about demand deposits. All forms of bank money are vulnerable.

Bank money is short-term debt. The critical feature of bank money is that it retains value so that it can act as a short-term store of value or such that other agents unquestioningly accept it in a transaction, without suspicion of private information held by the counterparty. Bills of exchange and negotiable instruments generally are bank money. This includes private bank notes, commercial paper, bankers' acceptances, money market funds, sale and repurchase agreements, and sight drafts. In fact, the history and evolution of various forms of bank money is rich and complicated. There are many kinds of bank money. See, e.g., Usher (1914), DeRosa (2001) and Ferderer (2003). Longer term bank debt that by design resembles government debt may also be included, that is, securitizations.

Checking accounts have not always been the primary form of bank money, and even today checks are being replaced by ATM machines and on-line banking. See Quinn and Roberds (2008). The issue of whether all forms of bank money are vulnerable to runs was brought to the fore by the recent crisis. The recent financial crisis was not a case of household depositors running on banks. It involved firms, financial and nonfinancial, foreign and domestic, running on shadow banks in the repo and asset-backed commercial paper markets. And, even this type of wholesale run is not new. See Quinn and Roberds (2012) and Schnabel and Shin (2004) who study a run in the wholesale market in Amsterdam in 1763. And, see Flandreau and Ugolini (2011) on the Overend-Gurney Panic of 1866 in England. It seems clear that runs have occurred under a variety of bank money forms. 
One of the most important forms of bank money historically was private bank notes. Private bank notes were issued by banks in many countries. Schuler (1992) finds sixty cases of such free banking in history. In some cases these notes were claims on a common pool of assets and in some cases they were not. In the U.S. under state free banking laws banks were required to back their notes with state bonds. In the case of a bank failure-an inability to honor requests for cash from noteholders - the state bonds would be sold (by the state government) and the note holders paid off pro rata. Note holders were paid off pro rata, so there was no common pool problem. Yet, there was a run on banks (banknotes and deposits) during the Panic of 1857.

The recent financial crisis centered on sale and repurchase agreements (repo). ${ }^{11}$ In a sale and repurchase agreement (a repo) one party lends/deposits money typically overnight at interest and this depositor receives a specific bond as collateral from the bank borrower. The lender/depositor must return the collateral at the maturity of the repo contract. There is no common pool of assets upon which the "depositor" has a claim. ${ }^{12}$ If the borrower/bank fails, then the lender/depositor can unilaterally terminate the contract and sell the collateral. Of course, a depositor need not renew the loan, and will not if there are concerns about the joint event of (1) the solvency of the bank and (2) the value of the collateral.

Repo and free banknotes are two examples of bank money where there is no common pool problem. Demand deposits and asset-backed commercial paper are examples where there is a common pool problem; these forms of bank debt are backed by a common portfolio of assets. We observe runs on both forms of bank money, suggesting that the common pool problem is not the inherent vulnerability.

Another special feature of the Diamond and Dybvig model is the fact that agents do not actually meet and trade, so there are no prices in the model. ${ }^{13}$ In the model, terms are set on the bank contracts initially and there are no subsequent prices because there is no subsequent trading among agents. In reality there are two complications. First, with many forms of bank money, including demand deposits and private banknotes, agents directly transact. One agent meets and, for example, writes a check to another agent in exchange for goods. Second, other forms of bank money have maturities; agents do not have the contractual right to withdraw any time.

\footnotetext{
${ }^{11}$ See Gorton (2010) and Gorton and Metrick (2012).

${ }_{12}$ Although see Martin, Skie, and von Thadden (2010).

${ }^{13}$ Jacklin (1987) discusses some of the trading restrictions in the Diamond and Dybvig model.
} 
In the Diamond and Dybvig model, once the agents have deposited money in the bank, there are no later transactions between depositing agents in the model. Some agents, perhaps all agents, go to the bank to withdraw prior to the realization of the investment payoffs. But, they do not transact directly with each other at some price, the price of goods in terms of the bank money. So, there are no prices in the model at the date when agents form beliefs about the actions of other agents.

But, in reality, agents do meet and trade goods or services for bank money. Before the U.S. Civil War when agents transacted they used private bank notes, the liabilities of banks denominated as money (i.e., one dollar bills, five dollar bills, etc.). An agent would go to the store and offer to buy goods with these notes. But, these notes did not trade at par. There was an exchange rate between the notes and gold. That is, there was a price. And prices contain information. It could be that one agent writes a check to another agent, for example. In this case, the relative price of the bank money in terms of goods plays a role, as in other markets. With demand deposits the price is usually par, except in a crisis when checks were discounted.

There are two cases. First, suppose there is a common pool problem. What is the effect of prices? Atkeson (2001) raises this point. In this case of the coordination problem, it is not clear that the multiplicity of equilibria disappears when prices are introduced. Economists have tried to address this issue and in related settings have found that the multiple equilibria remain in the presence of prices. See, e.g., Angeletos and Werning (2006) and Hellwig, Mukherji and Tsyvinski (2006). We would like to have a detailed theory of how beliefs are formed. This is an ongoing area of research.

The second case occurs where there is no common pool problem. There is no common pool problem in repo, for example. In a repo transaction there is a depositor who lends money and a bank borrower. The depositor receives interest on the loan, which is usually overnight. And the borrower delivers collateral to the depositor, which must be returned when the transaction matures. The collateral is sometimes "haircut," which means that the depositor lends less money than the market value of the collateral provided. For example, $\$ 90$ million is lent and the collateral is worth $\$ 100$ million at market prices. In repo, haircuts and interest rates depend on the identity of the counterparty if the collateral is private bonds. Even in an over-the-counter market, at any moment, agents in the market (eventually) know these prices. These prices are formed somehow and are related to agents' beliefs.

Another issue concerns how a crisis ends. If agents run on banks because they believe other agents will run, or because fundamentals have deteriorated, how does the crisis end? It is clearest to think of this 
before there is a central bank, say during the National Banking Era in the U.S. The run starts-for some reason, time passes, and then agents no longer want to run. Somehow agents' anxiety is assuaged, their beliefs are revised. But, we don't know how this happens. ${ }^{14}$ If the government or the central bank takes actions, then agents may revise their beliefs about whatever it was that caused them to run to start with. The details of what this means and how it happens are unclear. Before the Federal Reserve System was in existence, this puzzle is clearer. A run would start, usually in New York City, and banks would suspend convertibility. What happened during the period of suspension that allowed bank to resume convertibility? A model which can explain how a "loss of confidence" occurs needs also to explain how confidence is recovered. Clearly, a model with multiple equilibria as the "explanation" for a crisis has difficulties here. ${ }^{15}$

The Diamond and Dybvig setting is compelling. Private agents cannot produce debt that is invulnerable to runs. Only long-term private assets are available to back bank debt, which is needed to facilitate shorter-term transactions that some agents need to make to smooth consumption. But, the bank debt is vulnerable. And a crisis in Diamond and Dybvig is a distinct event. Building on Diamond and Dybvig requires a model in which a state of the world occurs causing everyone to run. ${ }^{16}$ Clearly, there is much work to be done. Incorporating credit booms into a crisis theory, explaining why there is an association between crises and prolonged recoveries, and explaining how a crisis ends, are all open questions.

\section{Bank Debt}

Let's take a step back and ask a general question: why is bank debt used for transactions? Agents could issue their own money. Or firms could issue money. In principle, the "money" could be equity or debt, or indeed, any security. Many such securities are traded in markets that are often described as "liquid." So, a basic question is why bank debt is used as money. Why banks? And why debt?

These questions are related to the notion of "liquidity," a term that is used in different ways in the economics literature. A central contribution of Diamond and Dybvig is their notion of "liquidity" as consumption smoothing. But, there is another notion of liquidity, a quite natural one first articulated by

\footnotetext{
${ }^{14}$ We know that the clearinghouses acted during crises, but we do not know how agents' beliefs were revised in response. We just know that eventually suspension of convertibility was lifted.

${ }^{15}$ That is, a "reverse" sunspot just compounds the problem of a lack of an explanation.

${ }^{16}$ There are other models of runs, as well. Diamond and Rajan (2001) show a model of bank fragility that is different than Diamond and Dybvig. It connects the asset side of banks to the liability side more specifically, showing that a kind of fragility is required, and displays a collective action problem. Another interesting example is Rochet and Vives (2004).
} 
Keynes and similar to traders' intuitive notions. Keynes wrote that an asset is liquid if its value is "more certainly realizable at short notice without loss" (Keynes $(1930,67))$.

Looking back to the Free Banking Era in the U.S. before the Civil War, one can get a sense of this notion of liquidity. Bank notes traded at discounts from par when the transaction was taking place at any distance from the issuing bank. The discount was uncertain and was determined in informal banknote markets where note brokers made markets and traded. The prices in these markets were reported in newspapers called "banknote reporters" that listed the discounts from par at particular locations. In Philadelphia for example, the banknote reporter would list the discounts on hundreds of notes. For example, a merchant arriving in Philadelphia from Savannah might be carrying the banknotes of a New Orleans bank. New Orleans is a quite a distance from Philadelphia and, depending on the year in which the transaction is taking place, it might have taken a week to ten days to get from Philadelphia to New Orleans. The discount on the note reflected this distance. Discounts were higher for more distant banks. In studying this market I showed that the discounts were not chaotic but rational. ${ }^{17}$ But still transacting with banknotes was a problem because the discount had to be determined in a market and recorded by the banknote reporter. Then the banknote reporter had to be consulted, arguments ensued, and the less informed party with weak bargaining power was possibly cheated. The pre-Civil War era is replete with constant complaints about bank notes.

Checks became more prevalent starting in the 1850 s and by the 1890 s were the dominant form of bank money in the U.S. The transition from bank notes to checks is a very important example of the change in the form of bank money. Demand deposits led to the system of "clearing," the process by which bank checks were returned to the bank where the depositor had an account. In the clearing process this bank would then honor the claim. With many banks, clearing in one location-- the clearinghouse-- netting of the claims could be accomplished.

It is important to understand that checks didn't exist then (or now) as a widespread form of money without (typically private) bank clearinghouses. Clearinghouses are inherent in demand deposits; they were part of the process which allowed checks to be efficient. Since checks must be "cleared" banks face enormous counterparty risk. In the clearing process, a bank may have a large positive net position with another bank. If that bank fails, then it could be disaster. Checks imply clearing, and clearing implies large counterparty exposures on a daily basis. This is the basis for the clearinghouse to assume a

\footnotetext{
${ }^{17}$ See Gorton $(1996,1999)$.
} 
monitoring and information production role. It makes no sense to think of checks without also thinking of clearinghouses.

Clearing internalized the note market. It allowed banks to monitor each other and created incentives to do so. The process of clearing in private bank clearinghouses meant that bank could enforce a price of par on in-state checks. ${ }^{18}$ This was accomplished by clearinghouse rules and regulations. This means that the information environment was fundamentally altered by the role of the clearinghouse. ${ }^{19}$ As a result, checks were more liquid than bank notes because they exchanged at par, except during a panic. With checks the problems of transacting were eased. Of course, the person's identity had to be checked, so transactions still took some time. But, the clearinghouse created liquidity and checks came to dominate private bank notes.

To stress the point, there can be no model of demand deposits without including clearinghouses. The clearinghouse internalized the market, in which bank notes had functioned. The clearinghouses ensured that checks traded at par. There were no discounts, as with banknotes. Note that this is important when agents meet and trade, suggesting that such trades should be included in a model.

Gorton and Pennacchi (1993) argue that banks exist to create trading securities that allow for transactions to be "more certainly realizable at short notice without loss," that is to trade a par without suspicions of counterparties or the backing assets of the checks. In particular, a holder of the security need not fear a loss of value to better informed parties when there is a transaction because the security is riskless. There can be no losses to better informed parties. But, Gorton and Pennacchi, like Diamond and Dybvig, did not explain why debt is the security banks issue for transactions. See Holmström (2008).

In Diamond and Dybvig the bank exists to smooth consumption, and in Gorton and Pennacchi the bank exists to produce a trading security that can be used without fear of loss to better informed traders. But, there remains the question of why these securities are debt. Existing theories of debt are not concerned with trading. They explain the existence of debt in settings focused on controlling the corporation, getting repaid when investing in a firm. The setting there is one in which the corporation

\footnotetext{
${ }^{18}$ Young (1910, p. 608) writes that the organization could expel weak banks, enabling "the clearing house as a body to exercise such supervision of any weak bank as to amount to a virtual taking over of its management till it is again in sound condition."

${ }^{19}$ See Cannon (1910), Gorton (1984, 1985), Timberlake (1984), Gorton and Mullineaux (1987), Richardson (2006), and Moen and Tallman (2010).
} 
has private information and the firm's output is not observable or not verifiable. There is no trade beyond the initial investment.

Holmström (2011) and Dang, Gorton, and Holmström (2012) provide a theory of debt as trading securities. They argue that debt is the optimal security for trading because it minimizes the incentive for a counterparty to produce private information about the payoff on the trading security. Adverse selection when transacting can then be avoided (most of the time). Riskless securities cannot be produced by the private sector. But, if agents can only produce information at a cost, then liquid securities are those which reduce the benefits of producing such information. Roughly speaking, debt minimizes the incentive to produce information because it has a bounded upside and that bound can be set as tight as possible by providing the debt holder with the maximum amount in the case of bankruptcy (the 45 degree line in case default occurs).

The debt is "information-insensitive" in two senses. It is immune to the counterparty producing private information in most states of the world, thus avoiding adverse selection. And, secondly, it retains the most value in the face of public information. But, such debt can sometimes become "informationsensitive." Dang, Gorton, and Holmström show that in the case of public bad news, it can be the case that a counterparty in a transaction finds it optimal to produce private information in which case the debt holder must accept adverse selection or trade at a price that is below the conditional expected value of the debt. These are instances of a crisis. A crisis displays the regime switch feature that I discussed above. There is a switch from information-insensitive debt to information-sensitive debt which then causes a collapse of trade.

Gorton and Ordoñez (2011) embed this idea of information-insensitive debt in a dynamic macroeconomic setting and show that a credit boom can occur when agents find that informationinsensitive debt is optimal. Over time more and more borrowing occurs because agents "forget" which collateral is high quality. Agents act as if most collateral is the average value, relatively high quality, and make loans on this basis. As the boom proceeds, a "small" shock can cause a switch to informationsensitive debt. A shock which would have no effect early on has a large effect when the boom has been ongoing for some time. The crisis is a sudden regime switch.

This is in contrast to models which display amplification or persistence-important effects to be sure, but which cannot display a crisis in the sense of a sudden regime switch. For example, in the model of Kiyotaki and Moore (1997) a shock is magnified via a feedback effect on the value of collateral. But, 
every shock, big or small, causes some feedback. There is a continuum of outcomes for a range of shocks, and a crisis must be a large shock. Similarly, in Bernanke and Gertler (1989) a shock creates persistence through reducing the net worth of firms resulting in lower borrowing and lower output. But, every shock results in this effect. ${ }^{20}$ My point is that these models cannot produce crises except via a "large" shock. Since the large shock is exogenous, this is not a theory of crises. ${ }^{21}$ On the contrary, Dang, Gorton, and Holmström show that fragility is endogenous, via the creation of debt that is informationinsensitive. Gorton and Ordoñez (2011) show how a credit boom can endogenously create fragility; a large shock is not required for a crisis.

A woman cannot be a little bit pregnant or a person a little bit dead. There is a crisis or there is not a crisis. This is an important point from Diamond and Dybvig. In Dang, Gorton, and Holmström the crisis occurs when privately-produced money endogenously becomes subject to adverse selection and loses its liquidity. Collateral that is information-insensitive is very hard information. And is the basis of private bank money. The crisis occurs when the collateral is no longer above suspicion, so to speak. The switch from information-insensitive to information-sensitive is the loss of "confidence" and corresponds to the regime switch. Holmström (2011) draws a number of other important implications from these ideas.

This model of debt and associated crisis is very different from the "frictions" incorporated into macro models. ${ }^{22}$ Simply put, these models do not generate crises. Kiyotaki and Moore (1997) and Bernanke and Gertler (1989) are now-since the crisis--cited as examples of the attention paid to financial frictions in macroeconomics. But, these models were not part of the formal modeling approach used in policy circles. Models addressing issues of the persistence of temporary shocks and the amplification of shocks are important. But, they cannot display crises. A macro model that can display a financial crisis is a distinct undertaking from a model which displays persistence of temporary shocks, real effects shocks to net worth, or from other financial frictions. As emphasized above, a crisis is a singular event, not the result of a large shock.

The notion of "frictions" arises when the benchmark model, the neoclassical growth model and complete markets cannot replicate important features of reality. In order to induce this model to replicate various features of reality one then adds "frictions." The benchmark model misses the fact

\footnotetext{
${ }^{20}$ Also see Bernanke, Gertler, Gilchrist (1999).

${ }^{21}$ And, to be clear, the authors of these papers never claimed that their models were such crisis theories. Others have made this claim since the financial crisis.

${ }^{22}$ See Bunnermeier, Eisenbach, and Sannikov (2012) for a survey of macro frictions.
} 
that private money is inherent in market economies. That bank debt is vulnerable to runs in market economies is a fact, like demand curves sloping downward. It is not a "friction" in that sense, but a fundamental feature of market economies. Once again, it is clear that there is much research to do. There are a number of (to me, anyway) exciting directions that are developing in macroeconomics. Examples include Brunnermeier and Sannikov (2010), He and Krishnamurthy (2012), and Maggiori (2012). These models incorporate financial sectors and do not focus on steady states. That is, they do not focus on linearized system dynamics around the steady state. So, they can display crisis-like behavior. On the other hand, while they incorporate financial sectors, the crisis is a big shock. The dynamics are triggered by a large shock which reduces the capital of banks, causing them to have to sell assets. While this may be viewed as a reduced form for a bank run, it is not, in fact, a run. Also see Boissay, Collard, and Smets (2012).

\section{Final Thoughts}

President Obama's chief of staff Rahm Emanuel observed during the crisis that: "You never want a serious crisis to go to waste," meaning that it is an opportunity to address long overdue problems in a major way. This is good advice for economists as well. The crisis revives old issues and raises new issues. The human toll from the crisis means that this is quite an urgent task. In order to address these issues documenting what happened during the recent financial crisis is critical to our understanding and remains the first task.

The recent crisis emphasizes a number of points. These are worth repeating. First, the recent crisis was a bank run, in the money markets. Secondly, the recent crisis emphasizes that a financial crisis is a distinct, regime switch-type, event. It was clearly different, worse, larger, than usual recessions. Thirdly, it showed (again) that crises recur in market economies. Fourthly, the crisis also showed that bank money without the common pool problem is vulnerable to runs. Fifth, it poses the question of why crises do not occur during certain periods. What regulation was successful? Sixth, the fact that basic institutions in the economy-banks, bank money-could transform largely without notice, means that our measurement systems are suspect. These are important lessons.

The first two points are the core of the concept of a crisis, while the third point emphasizes the fundamental nature of crises in market economies. The theory of crises needs to address the fourth point because, as an empirical matter, all forms of bank money are vulnerable. We know little about 
why there are long periods of quiet, about what bank regulations are effective or whether it was just good luck that produced these periods.

I have emphasized that empirical documentation of the crisis is critical, and that it is difficult for outsiders who did not see the crisis to know what to document. Finding data is hard, but crucial. Theory cannot be built on newspaper stories. 


\section{References}

Allen, Franklin and Douglas Gale (2000), “Financial Contagion," Journal of Political Economy 108, 1-33.

Angeletos, George-Marios and Ivan Werning (2006), "Crises and Prices: Information Aggregation, Multiplicity, and Volatility," American Economic Review 96 (5), 1720-36.

Atkeson, Andrew G. (2001), "Rethinking Multiple Equilibria in Macroeconomic Modeling: Comment," in NBER Macroeconomics Annual 2000, ed. Ben Bernanke and Kenneth Rogoff (MIT Press; Cambridge, MA), 162-171.

Barajas, Adolfo, Giovanni Dell'Ariccia, and Andrei Levchenko (2007), “Credit Booms: The Good, the Bad, and the Ugly," working paper.

Bernanke, Ben (2010), "Causes of the Recent Financial and Economic Crisis," Statement by Ben S. Bernanke, Chairman, Board of Governors of the Federal Reserve System, before the Financial Crisis Inquiry Commission, Washington D.C. (September 2, 2010); see http://www.federalreserve.gov/newsevents/testimony/bernanke20100902a.htm .

Bernanke, Ben and Mark Gertler (1989), "Agency Costs, Net Worth, and Business Fluctuations," American Economic Review 79, 14-31.

Bernanke, Ben, Mark Gertler and Simon Gilchrist (1999), "The Financial Accelerator in a Quantitative Business Cycle Framework," in John Taylor and Michael Woodford, eds., Handbook of Macroeconomics (Elsevier Science, North Holland; Amsterdam).

Boissay, Frédéris, Fabrice Colard, and Frank Smets (2012), "Booms and Systemic Banking Crises," European Central Bank, working paper.

Bordo, Michael and Joseph Haubrich (2009), "Credit Crises, Money, and Contractions: A Historical View," Federal Reserve Bank of Cleveland Working Paper No. 09-08.

Bordo, Michael, Barry Eichengreen, Daniela Klingbiel, and Maria Soledad Martinez-Peria (2001), "Is the Crisis Problem Growing More Severe?," Economic Policy 16, 51-82.

Bordo, Michael, Hugh Rockoff, and Angela Redish (1994), "The U.S. Banking System from a Northern Exposure: Stability versus Efficiency," Journal of Economic History 54, 325-341. 
Borio, Claudio and Mathias Drehmann (2009), "Assessing the Risk of Banking Crises-Revisited," BIS Quarterly Review, March, 29-46.

Boyd, John, Gianni De Nicolò, and Elena Loukoianova (2011), "Banking Crises and Crisis Dating: Theory and Evidence," International Monetary Fund, revised working paper.

Boyd, John, Sungkyu Kwak, and Bruce smith (2005), "The Real Output Losses Associated with Modern Banking Crises," Journal of Money, Credit and Banking 37, 977-999.

Brunnermeier, Markus and Yuliy Sannikov (2010), "A Macroeconomic Model with a Financial Sector," Princeton University, working paper.

Brunnermeier, Markus, Thomas Eisenbach, and Yuliy Sannikov (2012), “Macroeconomics with Financial Frictions: A Survey," Princeton University, working paper.

Caballero, Ricardo J., Takeo Hoshi, and Anil K. Kashyap (2008), "Zombie Lending and Depressed Restructuring in Japan," American Economic Review 98, 1943-77.

Calomiris, Charles, and Gary Gorton (1991). "The Origins of Banking Panics: Models, Facts, and Bank Regulation," in Financial Markets and Financial Crises, ed. Glenn Hubbard. Chicago: University of Chicago Press: 93-163.

Calvo, Guillermo (1995), "Varieties of Capital-Market Crises," in G. Calvo and M. King, eds., The Debt Burden and its Consequences for Monetary Policy (St. Martins Press: New York).

Cannon, James Graham (1910), Clearing Houses (Washington, DC: Government Printing Office).

Capie, Forrest and Geoffrey Woods, editors, ((2007), The Lender of Last Resort (Routledge; London and New York).

Caprio, Gerard and Daniela Klingebiel (1996), "Bank Insolvencies: Cross-Country Experience," World Bank Policy Research Working paper PRWP1620.

Caprio, Gerard and Daniela Klingebiel (1999), "Episodes of Systemic and Borderline Financial Crises," World Bank, working paper.

Carlsson, Hans and Eric van Damme (1993), "Global Games and Equilibrium Selection," Econometrica 61 (5), 989-1018. 
Cassis, Youssef (2011), Crises and Opportunities: The Shaping of Modern Finance (Oxford University Press).

Cerra, Valarie and Sweta Saxena (2008), "Growth Dynamics: The Myth of Economic Recovery," American Economic Review 98, 439-457.

Claessens, Stijn, M. Ayhan Kose, and Marco Terrones (2011), "Financial Cycles: What? How? When?," International Monetary Fund Working Paper No. WP/02/20.

Collyns, Charles and Abdelhak Senhadji (2002), "Lending Booms, Real Estate Bubbles, and the Asian Crisis," International Monetary Fund Working Paper No. WP/02/20.

Dang, Tri Vi, Gary Gorton, and Bengt Holmström (2012), "Ignorance and the Optimality of Debt," Working paper, Yale and MIT.

Dasgupta, Amil (2004), "Financial Contagion through Capitala Connections: A Model of the Origin and Spread of Bank Panics," Journal of the European Economic Association 2, 1049-84.

Dell'Ariccia, Giovanni, Enrica Detragiache, Raghuram Rajan (2008), "The Real Effect of Banking Crises," Journal of Financial Intermediation 17, 89-112.

Demirgüç-Kunt, Asli, and Enrica Detragiache (1998), "The Determinants of Banking Crises: Evidence from Developing and Developed Countries," IMF Staff Papers 45 (1): 81-109.

Demirgüç-Kunt, Asli and Enrica Detrachiache (2002), “Does Deposit Insurance Increase Banking System Stability? An Empirical Investigation," Journal of Monetary Economics 49, 1373-1406.

Demirgüç-Kunt, Asli and Enrica Detrachiache (2005), “Cross-Country Empirical Studies of Systemic Bank Distress: A Survey," National Institute Economic Review, No. 192, April.

DeRosa, Luigi (2001), "The Beginnings of Paper Money Circulation and Neapolitan Banks," Journal of European Economic History 30, 497-532.

Diamond, Douglas, and Philip Dybvig (1983), "Bank Runs, Deposit Insurance, and Liquidity," Journal of Political Economy 91,401-19.

Diamond, Douglas and Raghuram Rajan (2001), "Liquidity Risk, Liquidity Creation, and Financial Fragility: A Theory of Banking," Journal of Political Economy 109, 287-327. 
Diaz-Alejandro, Carlos (1985), “Good-Bye Financial Repression, Hello Financial Crash,” Journal of Development Economics 19, 1-24.

Djiwandono, J. Soedradjad (2000), "Bank Indonesia and the Recent Crisis," Bulletin of Indonesian Economic Studies, 36, 47-72.

Dornbusch, Rudi (2001), “A Primer on Emerging Market Crises,” NBER Working Paper No. 8326.

Elekdag, Selim and Yiqun Wu (2011), "Rapid Credit Growth: Boon or Boom-Bust,?” IMF Working Paper $W P / 11 / 241$.

Enoch, Charles, Barbara Baldwin, Olivier Frécaut, and Arto Kovanen (2001), "Indonesia: Anatomy of a Banking Crisis-Two Years of Living Dangerously, 1997-99," IMF Working Paper No. WP/01/52.

Federer, J. Peter (2003), "Institutional Innovation and the Creation of Liquid Financial Markets: The Case of Bankers' Acceptances," Journal of Economic History 63, 666-694.

Flandreau, Marc and Stefano Ugolini (2011), "Where It All Began: Lending of Last Resort and the Bank of England during the Overend, Gurney Panic of 1866," The Graduate Institute, Geneva, working paper No. 04/2011.

Freixas, Xavier, Bruno Parigi, and Jen-Charles Rochet (2000), "Interbank Relations, and Liquidity Provision by the Central Bank," Journal of Money, Credit and Banking 32, 611-638.

Furceri, Davide and Aleksandra Zdzienicka (2009), "The Effect of Banking Crises on Human Capital," working paper.

Goldstein, Itay and Ady Pauzner (2005), "Demand-Deposit Contracts and the Probability of Bank Runs," Journal of Finance LX, 1293-1327.

Gorton, Gary (1984), "Private Bank Clearinghouses and the Origins of Central Banking," Business Review-Federal Reserve Bank of Philadelphia, January/February, 3-12.

Gorton, Gary (1985), "Clearinghouses and the Origin of Central Banking in the United States," Journal of Economic History 45, 277-83.

Gorton, Gary (1988), “Banking Panics and Business Cycles," Oxford Economic Papers 40 (4), 751-81. 
Gorton, Gary (1996), "Reputation Formation in Early Bank Note Markets," Journal of Political Economy 104, 346-97.

Gorton, Gary (1999), “Pricing Free Bank Notes," Journal of Monetary Economics 44, 33-64.

Gorton, Gary (2010), Slapped by the Invisible Hand: The Panic of 2007 (New York: Oxford University Press).

Gorton, Gary (2012), Misunderstanding Financial Crises (New York: Oxford University Press; forthcoming 2012).

Gorton, Gary, and Andrew Metrick (2010), "Haircuts," Review-Federal Reserve Bank of St. Louis 92 (6): 507-520.

Gorton, Gary, and Andrew Metrick (2012), "Securitized Banking and the Run on Repo," Journal of Financial Economics 104, 425-451.

Gorton, Gary, and Don Mullineaux (1987), "The Joint Production of Confidence: Endogenous Regulation and Nineteenth Century Commercial Bank Clearinghouses," Journal of Money, Credit, and Banking 19, 458-68.

Gorton, Gary, and Guillermo Ordoñez (2012), "Collateral Crises," Yale Working Paper.

Gorton, Gary, and George Pennacchi (1993), “Financial Intermediaries and Liquidity Creation," Journal of Finance 45, 49-72.

Gourinchas, Pierre-Olivier, Rodrigo Valdes, and Oscar Landerretche (2001), "Lending Booms: Latin America and the World," Economia 1, 47-99.

He, Zhiguo and Arvind Krishnamurthy (2012), “A Macroeconomic Framework for Quantifying Systemic Risk," Kellogg School, Northwestern, working paper.

Hellwig, Christian, Arijit Mukherji and Aleh Tsyvinski (2006), "Self-Fulfilling Currency Crises: The Role of Interest Rates," American Economic Review 96 (5), 1769-1787.

Hoggarth, Glenn, Ricardo Reis, and Victoria Saporta (2002), "Costs of Banking System Instability: Some Empirical Evidence," Journal of Banking and Finance 26, 825-855. 
Holmström, Bengt (2008), “Discussion of 'The Panic of 2007,' by Gary Gorton,” In Maintaining Stability in a Changing Financial System, Proceedings of the 2008 Jackson Hole Conference, Federal Reserve Bank of Kansas City.

Holmström, Bengt (2011), "The Nature of Liquidity Provision: When Ignorance is Bliss," Presidential Address, Econometric Society, ASSA meetings, Chicago, January 5-8, 2012.

Jacklin, Charles (1987), “Demand Deposits, Trading Restrictions, and Risk-Sharing," in Ed Prescott and Neil Wallace, editors, Contractual Arrangements for Intertemporal Trade (University of Minneapolis Press; Minneapolis, MN), 26-47.

Jorda, Oscar, Moritz Schularick, and Alan Taylor (2011), "When Credit Bites Back: Leverage, Business Cycles, and Crises," Federal Reserve Bank of San Francisco Working Paper No. 2011-27.

Kaminsky, Graciela, and Carmen Reinhart. 1999. "The Twin Crises: The Causes of Banking and Balanceof-Payments Problems." American Economic Review 89, 473-500.

Kannan, Prakash (2010), "Credit Conditions and Recoveries from Recessions Associated with Financial Crises," IMF Working Paper No. WP/10/83.

Kelley, Morgan, and Cormac Ó Gráda (2000), “Market Contagion: Evidence from the Panics of 1854 and 1857," American Economic Review 90 (5): 1110-24.

Keynes, John Maynard (1930), A Treatise on Money, Vol. 2, The Applied Theory of Money )London: Macmillan).

Kindleberger, Charles (1978), Manias, Panics, and Crashes: A History of Financial Crises (Basic Books).

Kindleberger, Charles (1993), A Financial History of Western Europe (Oxford University Press; $2^{\text {nd }}$ edition).

Kiyotaki, Nobuhiro and John Moore (1997), “Credit Cycles," Journal of Political Economy 105, 211-248.

Laevan, Luc and Fabian Valencia (2008, 2012), "Systemic Banking Crises: A New Database," International Monetary Fund Working Paper 08/224 and WP/12/163.

Laevan, Luc and Fabian Valencia (2010), "Resolution of Banking Crises: The Good, the Bad, and the Ugly," International Monetary Fund Working Paper 10/146. 
Lockhart, Oliver (1921a), "The Development of Interbank Borrowing in the National Banking System, 1869-1914," Journal of Political Economy 29, 138-160.

Lockhart, Oliver (1921b), "The Development of Interbank Borrowing in the National Banking System, 1869-1914: II," Journal of Political Economy 29, 222-240.

Maggiori, Matteo (2012), “Financial Intermediation, International Risk Sharing, and Reserve Currencies," Stern School, New York University, working paper.

Martin, Antoine, David Skie, and Ernst-Ludwig von Thadden (2010), "Repo Runs," Federal Reserve Bank of New York Staff Report 444.

Mills, A. L. (1908), "The Northwest in the Recent Financial Crisis," Annals of the American Academy of Political and Social Science, Vol. 31, Lessons of the Financial Crisis, 113-119.

Mendoza, Enrique and Marco Terrones (2008), “An Anatomy of Credit Booms: Evidence from Macro Aggregates and Micro Data," National Bureau of Economic Research Working Paper No. 14049.

Mendoza, Enrique and Marco Terrones (2011), "An Anatomy of Credit Booms and Their Demise," working paper.

Moen, Jon, and Ellis Tallman (2010), "Liquidity Creation Without a Lender of Last Resort: Clearing House Loan Certificates in the Banking Panic of 1907," Federal Reserve Bank of Cleveland Policy Discussion Paper 2010-10.

Morris, Stephen and Hyun Shin (2001), "Rethinking Multiple Equilibria in Macroeconomic Modeling," NBER Macroeconomics Annual 2000, vol. 15, Ben Bernanke and Kenneth Rogoff, editors (MIT Press).

Ó Gráda, Cormac, and Eugene White. 2003. "The Panics of 1854 and 1857: A View from the Emigrant Industrial Savings Bank." Journal of Economic History 63 (1): 213-40.

Postlewaite, Andy and Xavier Vives (1987), "Bank Runs as an Equilibrium Phenomenon," Journal of Political Economy 95, 485-491.

Quinn, Stephen and William Roberds (2008), "The Evolution of the Check as a Means of Payment: A Historical Survey," Federal Reserve Bank of Atlanta Economic Review 93, 1-28. 
Quinn, Stephen and William Roberds (2012), "Responding to a Shadow Banking Crisis: The Lessons of 1763," Federal Reserve Bank of Atlanta Working Paper.

Rancière, Romain, Aaron Tornell, and Frank Westermann (2008), "Systemic Crises and Growth," Quarterly Journal of Economics 123, 359-406.

Ratnovski, Lev and Rocco Huang (2009), "Why Are Canadian Banks More Resilient?," IMF Working Paper No. WP/09/152.

Reinhart, Carmen and Vincent Reinhart (2010), "After the Fall," NBER Working Paper No. 16344, forthcoming in Federal Reserve Bank of Kansas City Economic Policy Symposium, Macroeconomic Challenges: The Decade Ahead at Jackson Hole, Wyoming, on August 26-28, 2010.

Reinhart, Carmen, and Kenneth Rogoff (2008), "Banking Crises: An Equal Opportunity Menace," NBER Working Paper 14587.

Reinhart, Carmen and Kenneth Rogoff (2009a), "The Aftermath of Financial Crises," NBER Working Paper No. 14656 ,

Reinhart, Carmen and Kenneth Rogoff (2009b), This Time is Different: Eight Centuries of Financial Folly (Princeton University Press).

Richardson, Gary (2006), "Correspondent Clearing and the Banking Panics of the Great Depression," National Bureau of Economic Research Working Paper No. 12716.

Rochet, Jean-Charles and Jean Tirole (1996), "Interbank Lending and Systemic Risk," Journal of Money, Credit, and Banking 28, 733-762.

Rochet, Jean-Charles and Xavier Vives (2004), "Coordination Failures and the Lender of Last Resort: Was Bagehot Right After All?," Journal of the European Economic Association 2, 1116-1147.

Schnabel, Isabel and Hyun Shin (2004), "Liquidity and Contagion: The Crisis of 1763," Journal of the European Economic Association 2, 929-968.

Schularick, Moritz and Alan Taylor (2009), "Credit Booms Gone Bust: Monetary Policy, Leverage Cycles and Financial Cycles, 1870-2008," American Economic Review, forthcoming. 
Schuler, Kurt (1992), "the World History of Free Banking: An Overview," chapter in The Free Banking Experience, edited by Kevin Dowd (Routledge; London).

Schwartz, Anna (2007), "Real and Pseudo-Financial Crises," Chapter 9 of The Lender of Last Resort, edited by Forrest Capie and Geoffrey Woods (Routledge; London and New York).

Sprague, o. M. W. (1910), "History of Crises Under the National Banking System," National Monetary Commission, U.S. Senate, $61^{\text {st }}$ Congress, 2d Session, Document No. 538 (U.S. Government Printing Office: Washington D.C.).

Timberlake, Richard (1984), "The Central Banking Role of Clearinghouse Associations," Journal of Money, Credit and Banking 16, 1-15.

Toujas-Bernaté, Joël and Hervé Joly (2011), "How Costly Are Debt Crises?," IMF Working Paper No. $\mathrm{WP} / 11 / 280$.

Upper, Christian (2006), “Contagion Due to Interbank Credit Exposure: What Do We Know, Why Do We Know It, and What Should We Know?," Bank for International Settlements, working paper.

Usher, Abbott Payson (1914), "The Origin of the Bill of Exchange," Journal of Political Economy 22, 566576.

Young, Stanley (1910), "Enlargement of Clearing House Functions," Annals of the American Academy of political and Social Science Vol. 36, No. 3, Banking Problems, 129-134.

Ziebarth, Nicolas (2011), "The Local Effects of Bank Failures on the Real Economy: Evidence from Mississippi during the Great Depression," Northwestern, working paper. 